\title{
Lego-Lego: An Attempt to Cultivate and Nurture Plurality and Multiculture in the Alor Tradition
}

\author{
Sastri Sunarti ${ }^{1}$, Atisah $^{2}$, Suryami $^{3}$, Winci Firdaus ${ }^{4}$ \\ Centre for Language Development and Language Preservation, Development and Cultivation \\ Agency, Ministry of Education and Culture, the Republic of Indonesia ${ }^{1-4}$

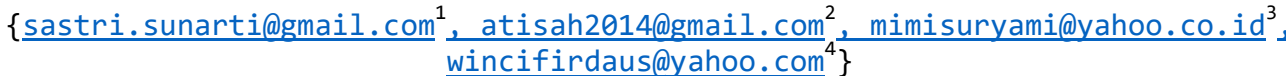

\begin{abstract}
Indonesia is a country which has a characteristic of cultural diversity. In Indonesia, the facts of plurality can be identified in around 650 local languages, 700 ethnic groups, and five religions. According to the facts, we can declare that Indonesia is a home for plurality. Today the plurality is challenged by exclusivism and primordialism. Recently, in Indonesia, several bombs blasted, and some people have been killed, and others are injured by the bomb. The unity among the people like Moslem and Christian is threatened un-united. This paper tries to offer a model of plurality, taking as an example, the oral tradition of The lego-lego performance which has been successfully cultivated and nurtured by the Alor people in Alor-Pantar island, East Nusa Tenggara. Alor-Painter has 18 local languages, 24 ethnic groups, and three major religions, which is a miniature of diversity in Indonesia. The lyrics of the lego-lego performance express the concepts of run kakang airing 'brotherhood,' and "toramiti tominuku" or "Haki-Haki tifang left Narang" 'unity in diversity.' Both concepts have been inherited through one of the traditions that are the "lego-lego" dance. This paper tries to show the experience to gain a mutual understanding of how to nurture diversity and reveal the inclusive identity of Alor in Indonesia.
\end{abstract}

Keywords: Plurality and Diversity, cultivating and nurturing, Lego-lego Dance

\section{Introduction}

Lately, research about plurality and multiculture have become important issue in Indonesia. The plural country like Indonesia is facing the problems of radicalism and terorism today, like the threats of fundamentalism, primordialism, exlusivism and mono-culture in spite of plurality. Suryadinata [1] said that with a population of approximately 206 million and more than 1000 ethnic and subethnic groups, Indonesia is undoubtedly one of the most ethnically and culturally diverse countries in the world. Suryadinata's statement is then supported by Azyumardi Azra[1], who is said stated that the substantive multicultural world view is not a new matter in Indonesia. As a nation that declared independence more than half a century ago, Indonesia actually owns and is composed of a large number of ethnic groups, cultures, religions, etc., so it can be called a multicultural society. 
Ignas Kleden [2] defined diversity as follows: if the term diversity is translated into terms of social science, then diversity can be defined as heterogeneity and diversity as a plurality. Heterogeneity is a concept of cultural anthropology to show cultural diversity that takes for granted that each culture and cultural group is seen as variants that differ from one another. With such limitations, it can be said that the Indonesian culture is very heterogeneous while German, Irish, Icelandic or Japanese cultures are relatively homogeneous. On the other hand, plurality is a term of political anthropology which affirms that cultural diversity is a reality that must be maintained and even championed and cultural differences are a legitimate right.

Besides the plurality concept, I also quote some opinions of cultural diversity like from Hikmat Budiman [3] who mentioned that the concept of cultural diversity refers not only to sources such as the multiplicity of ethnicity, race or culture in the territory of a country but also to many other sources.

However, for this study, this paper is limited to the communal diversity (plurality) which includes indigenous people, communities, religions, literary languages, and oral tradition. Referring to the plurality and multicultural constraints conveyed by the experts, the current diversity challenges in Indonesia should again look at the cultural approach that gave birth to the belief in diversity itself. The cultural approach meant here is a cultural approach based on the study of oral tradition that became one of the rich and varied forms of Indonesian cultural expression.

Figure 1. The Language Map of East Nusa Tenggara Province Courtesy of The Language Development and Fostering Agency
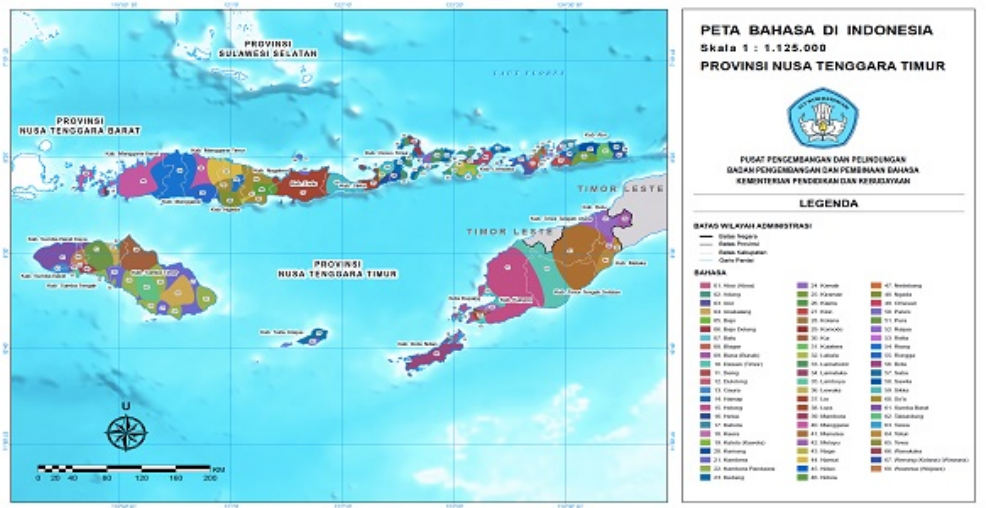

One example of the plural community in Indonesia is the Alor community, East Nusa Tenggara Province. Alor is the largest island in the Alor Archipelago and is one of the 92 officially listed outlying islands of Indonesia. It is located at the eastern Lesser Sunda Islands that runs through southeastern Indonesia, which from the west include such islands as Bali, Lombok, Sumbawa, Komodo, and Flores. To the east of the island across the Ombai Strait lie the islands of Wetar, and Atauru or now become East Timor. To the south, across the strait of Alor, lies the western part of Timor. To the North lies the Banda Sea and to the West lie Pantar and the other islands of the Alor archipelago, and further yet the rest of the Sunda islands (https://en.wikipedia.org/wiki/Alor_Island). Also, Alor is one of the regions of Indonesia. 
On the other hand, the language groups of Pantar and Alor, especially in the coastal areas, include Austronesian language groups. And the language groups from the Alor inland like Kui, Abui, Kamang, Klon, and Hamap include to the Non-Austronesian language groups or the Papuan language groups.

Based on the several descriptions above, we can see that Alor is a plural community. The plurality in Alor can be traced from the lego-lego performance as an oral tradition, which lives and thrives among the community is supported collectively and has been preserved for generations [4], [5]. In other words, as has been formulated by UNESCO, oral tradition is a tradition transmitted into space and time through speech and action [5].

\section{Literature review}

So far there have been several studies concerning the peoples of Alor, including Du Bois [6], Stokhof [7], Barnes [8], Dietrich [9], Gomang [10], Rodemeier [11], Mahsun and Fernandes [12], Katubi [13], Sunarti and Susamto [14]. According to Mahsun and Fernandez [12] Alor has 18 local languages, 24 ethnic groups, and 3 major religions, which are a miniature of diversity in Indonesia. Meanwhile, Gomang and Barnes [15] describe that the language spoken by the Alor people is the Alor language or Alurung language, which is a variety of Lamaholot. In the Pantar and Alor Archipelago, there are three groups whose language belongs to Lamaholot, that is, Baranusa and Pandai on Pantar and Alor/Alurung on Alor. Although these three groups possess the same language (differentiated only as dialects), each maintains its own identity. In daily life, the people of Pandai and Baranusa do not identify themselves as Alor people, and vice versa. In the distant past, the Alor language became a lingua franca for the peoples of Alor and Pantar.

\section{Method}

Most of the oral tradition based on the field research studies. Mostly, the field research studies use qualitative methode to collect data. According to Sweeney [16] there are five components for the researcher while in the field. The five components that is mentioned by Sweeney are finding informants, dealing with informants, recording, interviewing, and transcription. The primary data collect from interview with the key informants such the chief of the tribe or the head of village. Meanwhile, the audio and video recording is the most important technical to record the lego-lego dance performance. After the recording, data is trancripting to other language. The secondary data collect from the library research and other reference.

\section{Results and discussion}

\subsection{Result}

a. A cultural approach like the oral tradition study can be used to solve the problem of plurality and diversity in Indonesia.

b. For instance, the Lego-Lego dance performance in Alor represents multiculture learning among the people of Alor. The ancestors taught them how to cultivate and nurture the plurality which is in the several concepts like the alliance of regions 
(Galeyeo watang lema and Solor watang lema), and the alliance of religions (the Moslems and the Christians).

c. The medium for learning plurality is the Lego-Lego dance performance which is transmited orally. The oral tradition performance like the lego-lego dance has the lacking side which easy endangered. So, it needs the policy from the government of Alor to protect the Lego-lego dance performance. The protection can do transfer the Lego-lego dance into the school or transfer the values to the young generation.

d. The spirit of plurality can be seen as a cultural negotiation which reduced the differences among the Moslem and the Christian.

e. The lego-lego dance performance also functions as a medium which teaches the community the values of plurality. Through lego-lego poetry, the people of Alor can learn about mutual trust, mutual respect, and mutual understanding which is recited and presented from generation to generation.

\subsection{Discussion}

\subsubsection{The Lego-Lego Performance As A Way To Cultivate And Nurture Plurality}

So far, there have been few writings about lego-lego. Several writings that have discussed lego-lego, as Bouman [17] for example wrote "De Aloreesche Dansplaat", in Bijdragen tot de Taal-Land-en Volkenkunde van Nederlandsch-Indië, Deel 102,3de / 4de Afl. (1943), pages 481-500. Bouman describes the geographical characteristics of the Alor region, the ethnic group, the classification of language, and the life of the Alor people in the past that were heavily dependent on nature. Furthermore, Bouman explained that lego-lego was originally a form of homage of a sacred nature to the ancestral spirits. In addition, he mentioned that the lego-lego functions as a sign of relationship. However, then the sacred functions in the legolego performance faded due to the inclusion of Islamic and Christian teachings. Katubi [18] added that the ritual meaning of the lego-lego performance now has become ineffective for the three matters: (1) Islamic influence, (2) Christianizing, and (3) land cultivation. In addition, Katubi [18] defines the lego-lego as a poem (oral traditional poetry) sung while dancing in layered circles. The Lego-lego can be found all over Alor-Pantar region. In general, lego-lego is also known as a dance that is often performed during traditional ceremonies or after performing joint activities as an expression of gratitude after the rites of life have been performed like at a traditional circumcision. In the lego-lego performance we can find the oral history of the tribes in Alor and also the spirit of brotherhood among the tribes [14]. The legolego performers surround the mesbah (a circular stone/ an altar) while holding hands or hugging each other as an expression of unity.

However, Katubi's opinion is not true at all. Among the Muslim community of Alor Kecil (Minor Alor), Islam and the ancestor belief is continues. Before Islam and Christians were accepted by the Alor community, they had the belief to the Urfed Lahtal 'The Sun of God'. Every village and tribe like at Alor Kecil had the belief to the mesbah (a circular stone) as the center of the lego-lego ritual. The participant of lego-lego always around the mesbah during dancing. Dancing while surrounding the mesbah means that mesbah has functioned as a transcendental medium between man and God. For instance, when the people of Minor Alor celebrated sunna hada ritual (traditional circumcision), they are circled the mesbah even though they have already Moslems. In this area, Islam and the ancestor belief meet as the inclusivity. 
Rodemeier [11] describes the lego-lego in his thesis as a death rite. He discussed aspects of the dance using ritual equipment such as a gong and moko, and the dancers. Furthermore, he explained the lego-lego relationship with the ancestral spirits of Alor ancestors, ancestral journeys, mythology, and genealogy, including magical elements contained in the lego-lego performance. The magical element in this lego-lego performance, however, was also discussed by Bapa Abner Yetimauh (63 years old) a clan chief of Kapitang in Takpala village. For instance, when the Abui tribe from Takpala village danced lego-lego before hunting, they would touch the mesbah with their bow and arrow for luck. They believed that a mesbah could become smaller or larger depending on the size of the circle made by the lego-lego dancer while dancing as an expression of gratitude and joy (interview, April 5, 2017).

\subsubsection{The Nuh Mate and The Nuh Atinang Groups}

Culturally, the Alor people can be divided into two cultural regions. The first is the Nuh Mate, meaning people who are living at the big mountain or inland area, and the second is the Nuh Atinang, meaning people who are living in the small mountain or the coastal area. Most of the Nuh Mate people are Christian and they live in the hinterland. On the contrary, the Nuh Atinang people are Muslim and live in the coastal area. According to Stokhof (1984: 108£.), the Alor people reside in three principal villages, namely Alor Besar (Levong Beng, Large Village), Alor Kecil (Levo Kisu, Little Village), and Dulolong, these groups come from the Nuh Atinang/the little mountain). Besides these three principal villages, the Alor people also live on the northwest coast of Alor, and a portion resides in Ternate island and Buaya island. In addition to the Alor people, other groups living on the island of Alor include Adang/Kabola, Kui, Hamap, Kelong, Abui, Mataru, and Kolana (These groups come from the big mountain).

This division also identifies the group that performs the lego-lego. The lego-lego dance participants from Nuh Mate use some equipment for hunting like a bow and a sword for men, and anklets for women. Meanwhile, the lego-lego dance participants from Nuh Atinang usually use musical ornaments like the gong and the small drum. The difference between the Nuh Mate and the Nuh Atinang, according to Stuart (1990: 233), can be seen as the cultural identity. The cultural identity reflects the shared experiences and cultural codes in history that make them one unity. One of the cultural symbols in Alor is the lego-lego performance as we can see from the pictures below.

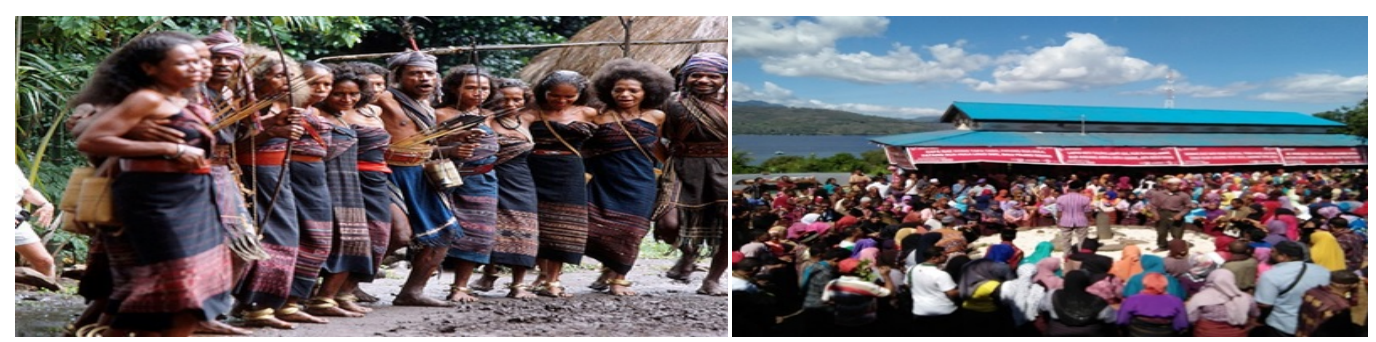

Figure 2. The Nuh Mate Lego-Lego dance performance Figure 3. The Nuh Atinang Lego-Lego dance performance

Even the Alor people can be identified by two cultural symbols; they have something in common sense as one Alor community. They united by the lego-lego dance performance 
which teaches them the meaning of unity in diversity. The poetry of the lego-lego expresse and describe the spirit of plurality and diversity. For instance, we can read below:

\author{
Alila Language \\ pidiai mamenu kafaing \\ tumhei tafuning nu aley \\ lamehorok doi taanlol \\ den buildon udeng til mel den tangamen \\ mopfo miliwang \\ tarifu husa elemek a'hal \\ mit tedun helto to malil
}

\author{
English Language \\ We are brother and sister \\ One placenta \\ The path of every mountain and the path of \\ every valley \\ Partly Christian and partly Moslem
}

But we do not fight each other

If there is a conflict

The lyrics of lego-lego indicate how the people in Alor cultivate and nurture the plurality through the legolego. The lyrics of lego-lego has function as a reminder for the community how to be an Alor people without neglect each other. Furthermore, the lego-lego performance represents of inter-religious relationships among Alor people.This poetry is always sung whenever the lego-lego is performed. The verbatim form of the legolego poetry is a simple and formulaic composition (Lord 1976 and Sweeney, 1987) which is easyly remembered by the lego-lego participants. As long as the lego-lego dance is still performed, the transmission of the plurality message is orally. The leaders of adat (traditional customs), the older people, are the key persons in the society who are always remind the young people to keep the harmony. In this case the lego-lego dance performance can be identified as the medium of the message [19]. In short, the goal of the lyrics of the legolego to internalize the plurality and diversity values in their lifes. The expression of the relationship between the Nuh Mate and the Nuh Atinang people is also expressed in the lego-lego poetry from the Takpala village like below.

\author{
The Abui Language \\ Pilanuku \\ piwea nuku beti \\ anuku hawali \\ adio bapil onhe \\ atenghu pil hawali \\ wala fuimiya \\ wala abumiya \\ fuimiya di poita masuiya \\ abumiya di pibale batako muria \\ di pi tama suiya \\ fuya Abui do afebeka lanuku
}

\author{
The English Language \\ The red blood (and) \\ The white blood are separated \\ By the creator \\ by the ancestors \\ who separate \\ partly on the beach \\ partly on the mountain \\ Water is taken from the sea \\ Tubers are planted at the mountain \\ take water from the sea \\ The mountain people and the coastal people \\ have always been united.
}

Besides in the lego-lego performance, the spirit of unity and diversity is also expressed in two expression which are Toramiti tominuku (in Abui language) and haki-haki tivang levo narang (in Alurung language) which is meaning 'unity in diversity". These expressions according to Sweeney[20], is signified as a stylized language form in the terminology of oral tradition. The stylized language form is used as a tool in the oral tradition community to remember the knowledge quickly and easily. It could be cultural and social modals for Alor people when dealing with the plurality and diversity. Instead of being different, they are united in diversity. With these strong values of tradition and identity, Alor communities have a spirit of unity conveyed through the 
lego-lego performances or in the stylized language form. Later on, The experession toramiti tominuku was engraved on a monument in Kalabahi and was also used as the name of a village, namely toramiti tominuku village.

\subsubsection{Alliance as a Form of Cultural Negotiation}

For a long time before the arrival of foreigners to Pantar and Alor, the people had sung the lego-lego poetry show the alliance between some kingdom territories in the past. The alliance mentions the kingdom of Galeo watang lema (The Galeo with the five beaches and Solor watang lema (Solor with the five beaches). Galeo is the other name of Pantar Island which is a part of the Alor region. As Gomang said [15], Solor, Alor, and Pantar were already for a long time in an alliance, or be a baja inAlurung Languade. Based on bela baja which is the same as the pela gandong alliance in the Moluccas, Ternate regarded itself as the power over Solor And Pantar, free to send an expedition in order to convert Alor and Pantar to Islam.

The alliance is expressed in the lego-lego sang performance. The language expression like the Galiau watang lema and the Solor watang lema means that the five kingdoms in Pantar and Alor (Pandai, Blagar, Baranusa, Bungabali, and Kui) had agreed with the five kingdoms in Solor watang lema 'Solor five beaches' (Solor, Adonara, Lembata, Lamakera, and Atauru). The alliance in the lego-lego song from Alor Besar and Alor Kecil established a harmonious relationship between two of great kingdoms from the past until nowThe harmonious relationship mentions the relationship between the rua kakang aring 'two older siblings', like stated by Raja Muda Sulaiman Tulimau in Alor Besar (interview, October 1, 2014). The harmonious relationship between the Galiau watang lema and the Solor watang lema is always recited by the liang pukong (the singer master) in the lego-lego dance performance like the poetry of the lego-lego from Pantar below.

\author{
Alurung Language \\ Galiau Solor watanglema \\ Beng Bungabali \\ Beng Bungabali naing homang \\ teleng naing homang \\ Solor watang lema \\ Kakang adonara \\ Galiao watang lema \\ Kakang Pandai \\ Galiau Solor watanglema \\ Beng Bungabali \\ Beng Bungabali naing homang \\ teleng naing homang \\ Solor watang lema \\ Kakang adonara \\ Galiao watang lema \\ Kakang Pandai \\ Ali-ali Baorae amang Baorae \\ Eti-eti lefo Bunga Bali \\ Ali-ali fatang Baorae \\ Bunga Bali Taruamang \\ Tanglapui nemo suroleing \\ Boti Taruamang \\ Rua kakang amang \\ Taruamang tana kotong \\ Juga tana tana kotong \\ Bunga Bali tana leing \\ Jaga tana leing
}

Eti-eti Bunga Bali Inang Bunga Bali

\section{English Language \\ Galiau Solor five beaches \\ Bungabali is the biggest \\ Bungabali is the biggest \\ hang its place}

Solor five beaches

Brother in Adonara

Galiao five beaches

Brother in Pandai

Galiau and Solor comprise five

beaches

Bunga Bali is the largest kingdom

Bunga Bali is the largest kindom

It is the largest kingdom

\author{
Solor's five beaches \\ Brother in Adonara \\ Galiao's five beaches \\ Brother at Pandai
}

It is Bunga Bali, Bunga Bali is the Mother

It is Baorae, Baorae is the Father

It is Bunga Bali village

It is Baorae beach

Baorae at the beach

Bunga Bali Taruamang

Tanglapui decline path

Supported Taruamang

The two of siblings

Taruamang is the head of the land

Keep the head of the land

Bunga Bali is the tail of the land

Keep the tail of the land 


\subsubsection{Moslems and Christians Alliances as Multiculture Learning}

The other alliances that shown in the lego-lego poetry are the alliance between the Moslems and the Christians community, like at the Alila and Moraman villages. The Muslim community help the Christians built a church and in 1951 brought a priest to Alila. The harmonious between the two community in Alila is continuous until now. In 1991 when the earthquake struck Alor, the church collapsed and rebuilt a year later. Church was later renamed. The renovation of the church after the earthquake was also assisted by the Muslim community. During the restoration of the church, it was guarded by the Muslim community until the installation of a church board was completed. The Imam (Muslim leader) and the other Moslem bring the Cross to the New church. They paraded the cross along the path of Alila village while played the Qasidah Music. The village of Alila Timur have population of approximately 165 people and the village is in the altitude area. The Ismail church congregation currently consists of 45 families, (interview with Kauren Lokabola, aged 54 years, the village of East Alila, 6 April 2017).

The interfaith alliance between Moslem and Christian is represented in the lego-lego sung poetry follows.

Abui Language
pidiai mamenu kafaing
tumhei tafuning nu aley
lamehorok doi taanlol
den buildon udeng til mel den tangamen
mopfo miliwang
tarifu husa elemek a'hal
mit tedun helto to malil
umasigi bangpalola
mang tanaii omle midek
mang tanai omle mitee

\section{The lego-lego poetry of East Alila Village}

English translation

We are brother and sister

We come from of the one placenta

\author{
The path of every mountain and an every \\ valley \\ Partly of Christian and partly of Moslem \\ we do not igonore each other \\ we keep our village \\ the mosque is the sacred place \\ Prohibit to non Moslem \\ do not enter \\ but, we let the other come inside \\ even for the dogs \\ in the Moslem and the Christian kitchen
}

The metaphor which described of unity in the sung lyric of lego-lego is the brother and sister (rua kakang aring). This metaphor has symbols of the blood bond which is beginning since the pregnancy. Thus the unity among the Alila people is strong and compact. It means no one can break the unity among them. In their opinion, it is illogical if the Moslem and Christian neglected each other.

On the other hands, the interfaith alliances between Moslems and Christians can also be found in the Alor Southwest district. The district consists of 16 villages namely Moru, Morba, Maiwal, Kafelulang, Wakapsir, Wakapsir Timur, Pailelang, Probur, North Probur, Wolwal Mukuk, South Wolwal, The West Wolwal, The Nort Wolwal, Matareben, Wormanen and Moraman villages. Most of the people are Catholic. But there are one village namely Moraman which is Moslem. The number of Moslem in this village is only 10 percent of people. The Moslem community in the Moraman village had the favor from the Christian Community even they are the majority. Due to the research at Moraman, I saw the harmonious relationship between Moslem and Christian.

Besides helping the Moslems built the mosque, in Moraman the Camat (the head of the region) is a Moslem person. The spirit of unity in diversity in the Southwest Alor district, allowed them to have a leader from the differences the religious belief. The majority of Christians agree to be lead by a Muslim person. It shows us how the plurality is cultivated and nurtured successfully in Alor. According to Syafuddin Djawa (the head of the Southwest Alor region) said that the values of mutual understanding and mutual respect among the people is the result of the faith and belief that religion is something that came from the sea (the outside) and the blood of Alor people come from the Alor land. Therefore, they can overcome 
differences of religion among them. They do not feel threatened by each other despite differences in religious beliefs. In this level, Alor people have overcome the problems of diversity and since long ago live together in harmony. The beliefs as the Alor community keeps them, from the clashes. When they have problems, it could solve by adat (customs) which had been taught by their ancestors since long ago. Adat has become the supreme law among them not the other rules. And the adat rule always transmitted in the lego-lego dance performance.

\subsubsection{The Egalitarian Spirit in The Lego-Lego Performance}

In Malay expression, there is one popular proverb which is quoted all the times. The expression is introduced like this: "although the orange fruit is in the mountain and the salt is in the sea they are united in the cauldron." This expression can be used to describe the harmony of plurality in Alor. The spirit of unity can be seen from The lego-lego performance participants. The participants both men and women dance together in a circle. They dance arm in arm as the symbol of the unity.

The number of the lego-lego performance participant is approximately fifty to one hundred people, sometimes even more. The participants usually use woven sarung. The spirit of equality among the Alor people can also be seen while they are dancing the lego-lego. The adat chief and the simple people dance at the same level, and there is no stratification during the performance. Every individual has the same position in the lego-lego performance.

According to Usman Mautang (the group leader of the lego-lego). The lego-lego performance is performed on several events, for instance (1) at the renovation of a mosque or church, (2) the celebration of the independence day, and (3) The welcoming of an important guest.

\subsubsection{The Challenge of Plurality in Alor and Indonesia Today}

Up to know, the lego-lego performance still practices in most areas of Alor. However, in some part of Alor like Kafoa, its practice has been prohibited by the church as teaching deviating from the true religion. When the lego-lego extinct, automatically the values of plurality in the lego-lego poetry will also be extinct. It is important to keep the transmission of the lego-lego performance. And as the transmission is done orally, and has not been put in writing, it can easily disappear, particularly because it has not been put in the school curriculum. So, when the old generation pass away, the younger generation will not be familiar with the valuable teachings mention above. Therefore, the tradition of protection lego-lego is very important to preserve. But the lego-lego poetry which contains plurality value should be written and should be reproduced over and over in any form and medium. The lego-lego performance and the text of plurality can also be taught in new and modern ways starting from the elementary school onwards.

The big challenge of plurality and multicultural in Indonesia today is exclusivism despite inclusivism. Jakarta as the capital city of Indonesia faces of the disruption of plurality. For instance, the election of the Governor Basuki Tjahaya Purnama (Chinese blood and Christian) is finally with by the rejection of some group of the community, like Moslem. But the rejection is not fair and by design by the capital power. The social situation after the election is in strong contrast with before the election. The unity in diversity is going well before the election. The Jakarta is the heterogeneous community since long ago. They realize that there is a diversity among them. But after the Governor election began, the demonstrations who is 
demanded the resignation of Basuki Tjahaya Purnama. In short, the primordialism and political agreement are used in the contesting of the power and Governor election in Jakarta.

Those phenomena then spread away to other province and region like Alor. The election of the mayor, The Camat, and the chiefs of kampong has infected by the political interest, exclusivism, anti-plurality, and the narrow perspective among the community. Furthermore, the information from the internet which is without selected make the situation become worst and decline. Indonesia needs control of using internet access. Most of the internet users are not mature and smart face on the use of technology. The good news and the worst news like hoaxes is so easy to find and to share by the internet user. This situation is not a normal life or the normal situation for the Jakartan or Indonesian. That's way, we need to develop and formulate the cultural approach like in the Alor island.

\section{Conclusion}

The plurality among the Alor people has existed for a long time. This diversity can be identified from the cultural symbols like the Nuh Mate and the Nuh Atinang, or the Moslem or the Christian, languages, and the tribes. The diversity is a historical fact in the community. Even though diversity has potential conflicts among the community, they have some strategies to avoid them. This strategy is recognized as the local wisdom. Within the local wisdom, they prove to others, that plurality and diversity among them is not a reason for clashes each other.

The ancestors taught them how to cultivate and nurture the plurality which is in the several concepts like the alliance of regions (Galeyeo watang lema and Solor watang lema), and the alliance of religions (the Moslems and the Christians). The medium for learning plurality is the lego-lego dance performance which is transmited orally. The poetry of lego-lego contain some values on how to be a plural community. For instance, in the lego-lego poetry there is a metaphor and concept of brotherhood (rua kakang aring) and toramiti tominuku (unity and diversity). The spirit of brotherhood and unity and diversity come from the land of Alor, while the religion comes from the sea (from the outside). It means no one can break the unity among them. On the other hand, it is illogical if Moslems and Christians neglected each other.

The spirit of plurality can be seen as a cultural negotiation which reduced the differences among them. The lego-lego dance performance also functions as a medium which teaches them the values of plurality. Through lego-lego poetry, the people of Alor can learn about mutual trust, mutual respect, and mutual understanding which is recited and presented from generation to generation. Unfortunately, the knowledge of plurality in the lego-lego performance is only mastered by the old generation, so, when they pass away the knowledge will vanish, too. As long as the transmission of the lego-lego dance performance continues in Alor, the plurality is always alive, cultivated and nurtured in Alor. Therefore, it is important that the lego-lego performance prevails and that the lyrics which shows plurality is reproduced and taught in the new and the modern ways and need to transfer to the school institution.

\section{References}

[1] L. Suryadinata, E. N. Arifin, and A. Ananta, Indonesia's Population: Ethnicity and Religion in a Changing Political Landscape. Singapore: Institute of Southeast Asian Studies, 2003.

[2] I. Kleden and T. Abdullah, Paradigma Ilmu Pengetahuan dan Penelitian Ilmu-Ilmu Sosial dan Humaniora di Indonesia. Jakarta: LIPI Press, 2017. 
[3] H. Budiman, Hak Minoritas: Ethnos, Demos, dan Batas-Batas Multikulturalisme. Jakarta: The Interseksi Foundation, 2009.

[4] Y. Rusyana, Metode pengajaran sastra. Bandung: Gunung Larang, 1982.

[5] S. S. Hutomo, Mutiara yang terlupakan: Pengantar studi sastra lisan. Surabaya: Himpunan Sarjana Kesusastraan Indonesia, Komisariat Jawa Timur, 1991.

[6] C. Du Bois, The people of Alor. New York: Harper Torchbooks, 1944.

[7] W. A. L. Stokhof, Beberapa Catatan Mengenai Bahasa Terancam di Pulau Alor dan Pantar (Indonesia Timur). Pinang: Penerbit USM, 2016.

[8] R. H. Barnes, "Two terminologies of symmetric prescriptive alliance from Pantar and Alor in Eastern Indonesia," Sociologus, vol. 23, no. 1, pp. 71-89, 1973.

[9] S. Dietrich, "A note on Galiyao and the early history of the Solor-Alor islands," Bijdr. tot Taal-, Land-en Volkenkd., vol. 2, no. 3, pp. 317-326, 1984.

[10] S. R. Gomang, "The people of Alor and their alliances in Eastern Indonesia: a study in political sociology," University of Wollongong, 1993.

[11] S. Rodemeier, "Local tradition on Alor and Pantar: an attempt at localizing Galiyao," Bijdr. tot Taal-, Land-en Volkenkd., no. 3de Afl, pp. 438-442, 1995.

[12] M. Nugroho, "Menggali Nilai-Nilai Budaya dalam Peribahasa Etnis untuk Materi Pelajaran Muatan Lokal Bahasa dan Sastra Daerah dalam Pembentukan Wawasan Keindonesiaan: Perspektif Antropolinguistik," Mabasan, vol. 2, no. 2, pp. 89-108, 2008.

[13] M. Y. F. Akoli, "Semivowelization and Alveolarization in Kui Language."

[14] S. Sunarti, "Suara-Suara Islam dalam Surat Kabar dan Majalah Terbitan Awal Abad 20 di Minangkabau," Bul. Al-Turas, vol. 21, no. 2, pp. 113-124, 2015.

[15] S. R. Gomang and R. H. Barnes, "Serinta behind the Traditional Poetry of the Alor People of Belagar and Pandai in Pantar, Eastern Indonesia," Anthropos, vol. 102, no. 2 , pp. 570-578, 2007.

[16] B. A. van Nooten and P. L. A. Sweeney, "The Ramayana and the Malay Shadow-Play," J. Am. Orient. Soc., vol. 98, no. 4, p. 566, Oct. 1978.

[17] M. A. Bouman, "De Aloreesche dansplaats," Bijdr. tot Taal-, Land-en Volkenkd. van Ned., vol. 3, no. 4, pp. 481-500, 1943.

[18] A. Schapper and E. Wellfelt, "Reconstructing contact between Alor and Timor: Evidence from language and beyond," NUSA Linguist. Stud. Lang. around Indones., vol. 64, pp. 95-116, 2018.

[19] M. McLuhan and L. H. Lapham, Understanding media: The extensions of man. New York: MIT press, 1994.

[20] A. Sweeney, A full hearing: orality and literacy in the Malay world. California: Univ of California Press, 1987. 